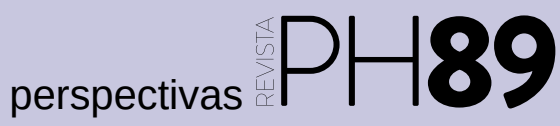

a debate Patrimonio, turismo y género. Estrategias para integrar la perspectiva de género en el patrimonio histórico

| coordinan Margarita M. Birriel Salcedo, Carmen Rísquez Cuenca

\title{
Joc de Dames, un proyecto muy normal
}

Cristina Simó Espinosa | Ecomuseu de les Valls d'Àneu

Noemí Nus | Peperepep Cultural

URL de la contribución <www.iaph.es/revistaph/index.php/revistaph/article/view/3717>

Trabajamos como gestoras patrimoniales y guías interpretadoras en dos comarcas vecinas del Pirineo catalán. Siempre con perspectiva de género. Al hacerlo no sólo no nos negamos a nosotras mismas sino que aportamos para acabar con el patriarcado. Desde hace un año, con el proyecto Joc de Dames, coordinamos las visitas a nuestros espacios contando el hilo histórico que los une (sin compartimentarlo, como se suele hacer) y nuestra normalidad es hablar de las mujeres que junto con los hombres fueron protagonistas. Hasta ahora apenas se había dicho nada sobre ellas. Nos hemos basado en la investigación (iiidifícil!!!), en la intuición y en las gafas lilas. No anunciamos una actividad especial para mujeres ni sobre ellas. No. Siempre hemos estado, así es
$C^{n}$

ns hem posat d'acord! De fet ja fa temps que ho vam fer, $i$ ara tenim un

Què va passar als segles xi i xIr al Pallars?

Les entitats que gestionem el castell i la canònica de Mur, Santa Maria de Gerri, Sant Pere del Burgal i Santa Maria d'Aneu ho tenim clar, no us volem explicar només fragments d'història. Vosaltres la voleu saber tota.

Ês per això que per conèixer bé els 4 espais i els estrets lligams que tenen, voldreu anar de l'un a laltre. A cada lloc us anirem explicant com va ser el Joc de dames, com es va percebre des d’aquell indret, i com va transcórrer la història posterior.

Us oferim aquesta ruta, amb visió integral, amb visió de gènere, parlant de les dones i els homes que van fer la història.

Com va ser, com ha de ser.

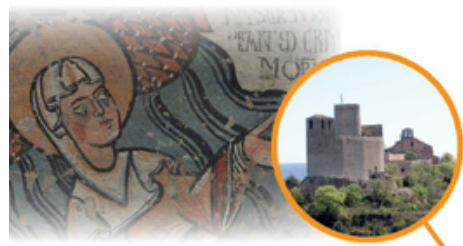

Castell de Muri candnica de Santa Maria

Castell $\mathrm{i}$ canònica agustina $\mathrm{S}$. $\mathrm{x}$-xI-xII, restauracions s. xx-xxı. Millor castell romànic de Catalunya. Es completa amb lesglésia. Amb reproducció de les pintures romìnigus les primeres venudes de totel Pirineu català

Personatges històrics: Arsenda, Arnau Mir de Tost, Valença, Ramon de Pallars, Puig i Cadafalch, Folch $\mathrm{i}$ Torres $\mathrm{i}$ altres.

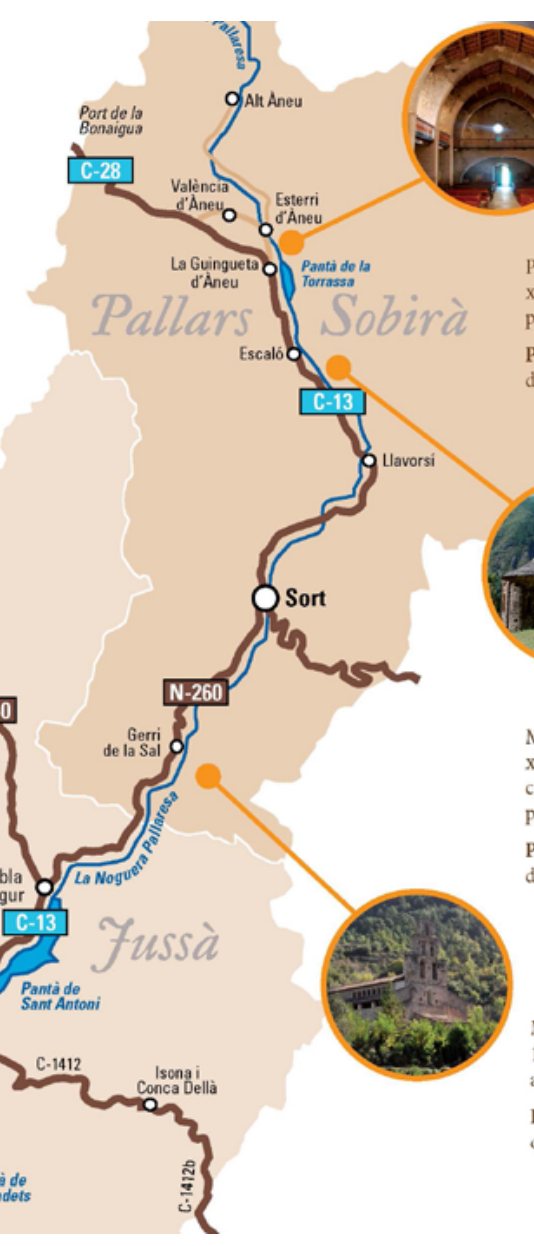

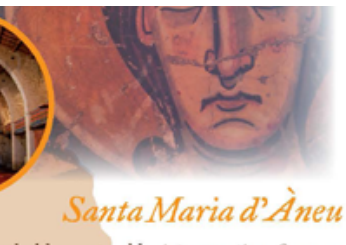

Probablement col-legiata agustina. S. IX, xI-XII, xvXVI, restauraciós. xx-xxi. Amb reproducció de les pintures romàniques.

Personatges històrics: Llúcia de la Marca, Artau I de Pallars, Caterina Albert de Pallars i altres.

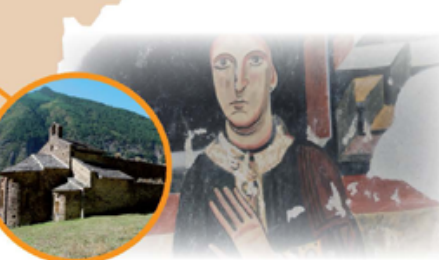

Sant Pere del Burgal

Monestir benedictí (parcialment enrunat). S. ix, xI-XII, restauració s. Xx i xxı. Església de doble capçalera, fet molt rar. Amb reproducció de les pintures murals romàniques.

Personatges històrics: Ermengarda abadessa, Llúcia de la Marca, Artau I, Artau II, Llúcia, Ot i altres,

\section{Antic monestir} de Gerride la Sal

Monestir benedicti. S. IX, modificant-se al llarg de 1,000 anys. Restauraciós, xxi xxy. Romànic tardà amb escultura de pedra. Reformes barroques. Personatges històrics: Espanell, Ot $\mathrm{i}$ altres. Pot ser que no hi ha hagi cap dona vinculada?

Interior del folleto divulgativo de la ruta Joc de Dames 
a debate Patrimonio, turismo y género. Estrategias para integrar la perspectiva de género en el patrimonio histórico

| coordinan Margarita M. Birriel Salcedo, Carmen Rísquez Cuenca

que lo más normal es que se hable de nosotras, ¿verdad? (Bueno, nuestra intención en realidad no es taaaan inocente, claro... ) Es fácil observar que las mujeres, en estas visitas, levantan las orejas, sumamente interesadas por un discurso que las incumbe. ¡Todo cambia! Y nos alegramos muchísimo cuando se despierta el interés masculino. Es otro de nuestros objetivos.

Algo que creemos que la perspectiva de género puede aportar al patrimonio es tener presente que el supuesto "olvido" histórico de las mujeres suele deberse a las relaciones de poder existentes. No creemos que a las mujeres se las haya olvidado, sino que de forma pretendida e intencionada se ha usado el olvido para silenciar aportaciones culturales y sociales que remueven los cimientos del poder dominante. Iluminar estos mecanismos, no sólo logra poder conocer mejor los procesos históricos en los que se desarrollan, sino también cualquier elemento patrimonial. El silencio es el olvido. En Joc de Dames no queremos olvidar porque no queremos silenciar y esto implica divulgar todas las voces que forman parte de la historia.

Sobre el texto de Galeano ${ }^{1}$ : se nos ocurre que claro que ellas también pintaron, ¿por qué no? Creemos que esto de que los hombres eran unos brutos en una sociedad machista y violenta está por ver. Para nosotras que esto se inventó cuando se empezaron a estudiar estas sociedades. Siglos XVIII-XIX. Patriarcado. ¿Quién estudiaba, o qué estudios nos han trascendido? Sólo los de los hombres, que al estar educados en ese modelo, veían según él. Si educamos y estudiamos en un modelo igualitario, seguro que veremos cosas muy distintas.

\section{NOTA}

1. Fragmento del libro Mujeres, de Eduardo Galeano, propuesto como uno de los elementos de reflexión para el debate: "Están allí pintadas las paredes, los techos de las cavernas; alces, bisontes, figuras que vienen de eso que Ilaman Prehistoria; caballos, fieras, hombres, mujeres que no tienen edad. Fueron pintadas, pintados, hace miles y miles de años, pero nacen de nuevo cada vez que alguien las mira. Y uno se pregunta: ¿Cómo pudieron ellos, nuestros remotos abuelos pintar de tan delicada manera?, ¿Cómo pudieron aquellos brutos que peleaban mano a mano con las fieras más feroces, crear esas figuras tan, tan plenas de gracia, esas mágicas obras volanderas que se escapan de la roca y por los aires vuelan?, ¿Cómo, cómo pudieron ellos?... ¿O eran Ellas?" 